Наукові експедиції

\title{
Report by Poznań biology students on an educational expedition to Kherson Region, Ukraine
}

\author{
SYLWIA ŁUKASIK \\ KRZYSZTOF DUDEK \\ MONIKA GAWALEK \\ MONIKA ZGRABCZYŃSKA
}

\begin{abstract}
ЛУКАСІК С., ДУДЕК К., ГАВАЛЕК М., ЗГРАБЧИНСЬКА М., 2011: Звіт студентів-біологів Познаньського університету про експедицію в Херсонську область (Україна). Чорноморськ. бот. ж., Т.7, № 1: 94-97.
\end{abstract}

В статті подаються матеріали спільної наукової експедиції студентів біологічного факультету Познаньського університету імені Адама Міцкевича та студентів Херсонського державного університету, яка була проведена на території Херсонської області (Україна). Були досліджені природні ценози центральної частини південної України біосферних заповідників- «Асканія-Нова ім. Ф.Е. Фальц-Фейна та «Чорноморський».

Ключові слова: наукові експедиії, Херсонська область, південна Украӥна

Łukasik S., Dudek K., Gawalek M., Zgrabczyńska M., 2011: Report by Poznań biology students on an educational expedition to Kherson Region, Ukraine. Chornomors'k. bot. z., Vol. 7, № 1: 94-97.

The article comprises a report from an educational expedition students of Faculty of Biology at Adam Mickiewicz University to the Kherson Oblast, which was possible thanks to the cooperation with Kherson State University. The aim was to get acquainted with the natural peculiarities of the central part of southern Ukraine, inter alia two national reserve Askania Nova Reserve and Black Sea Biosphere Reserve.

Keywords: educational expedition, Kherson Oblast, southern Ukraine

ЛУКАСИК С., ДУДЕК К., ГАВАЛЕК М., ЗГРАБЧИНСКАЯ М., 2011: Отчет студентовбиологов Познанского университета об експедиции в Херсонскую область (Украина). Черноморск. бот. ж., Т. 7, № 1: 94-97.

В статье подано материалы совместной научной экспедиции студентов биологического факультета Познанского университета имени Адама Мицкевича и студентов Херсонского государственного университета, которая была проведена на территории Херсонской области (Украина). Были исследованы природные ценозы центральной части южной Украины - биосферных заповедников «Аскания-Нова» им. Ф.Э. Фальц-Фейна и «Черноморский».

Ключевые слова: научные экспедиции, Херсонская область, южная Украина

We reached the "sea of sunflowers", as we sometimes felt admiring the surrounding scenery, when in July 2010, students of Faculty of Biology at Adam Mickiewicz University went on an educational expedition to the Kherson Oblast. Our aim was to get acquainted with the natural peculiarities of the central part of southern Ukraine. During this expedition, which lasted for two weeks, we travelled from Kherson through the Black Sea Biosphere Reserve to the southernmost town of the reserve - Zaliznyj Port, altogether almost 1,000 km.

( С С. Лукасік, К. Дудек, М. Гавалек, М. Зграбчинська Чорноморськ. бот. ж., Т. 7, № 1: 94-97. 


\section{Wandering through the steppe...}

Despite the ever persistent high temperatures and burning sun, we crossed the mosaic of different steppe types listening to the explanations of our tutors - dr. Zoja Selyunina, dr. Olga Umanec and Darya Chernyakova. The first place we visited, was locally known as "sands". This was an area of inland dunes, which until recently was used as a military training ground, of which was reminded by pieces of rusty metal, hidden in the sand. We have seen many new species, mostly plants, since animals inhabiting these areas were conducting secretive or nocturnal lifestyle.

Gold and yellow flowers of Tragopogon borysthenicus Artemcz., Euphorbia seguieriana Neck., white of Centaurea breviceps Iljin. and Allium guttatum Stev. as well as delicate violet of Thymus borysthenicus shimmered between the psammophilous steppe, including Stipa borysthenica Klok. et Shost. protected on the territory of Ukraine. On sandy slopes, we also noted some pioneer species such as: Agropyron desertorum (Fisch. et Link.) Schult. et Schult. F., or Linaria dulcis Klok. In local depressions of contemporary aeolian origin, bushes formed by Betula borysthenica Klok., an endemic plant of Kherson region, have developed. In the moderately wet depressions of psammo-steppe we have spotted highly specialized insectivorous plants, such as Drosera rotundifolia L. We were extremely impressed that those tiny plants formed a dense carpet.

These apparently wild steppes were not free of invasive species. One of them was an alien of north American origin Ambrosia artemisiifolia L. The another threat to the steppe vegetation was the observed expansion of an extremely unwelcome Eleagnus angustifolia L. This shrub has already been used in the nineteenth century as an ornamental plant in the southern regions of Ukraine. Its abundant fruits are eaten by blackbirds, which contribute to the spreading of this species [PROTOPOPOVA et. all 2006].

Our tireless steppe guides perfectly sensed the moment in which we all got hungry. Bread, pork fat and cucumbers were delicious and filling food. We ate them in a familiar atmosphere and in the comfort of the irreplaceable jeep. Unused to such a warm climate, happy, but exhausted, we returned to the Central Station of the Black Sea Biosphere Reserve.

We arrived to Hola Prystan via attractive and unusual for us means of transportation the river ferry. During the trip, we could observe flying and swimming pelicans in the calm estuary of the Dniester. On the spot, it turned out that in the Hola Prystan was situated the main research base of the Black Sea Biosphere Reserve. It is a nature reserve with an almost 90 years long tradition. On its territory, during the passage, one could see over 300 species of birds, 26 of which were mentioned Red Book of Ukraine and Kherson oblast' [BOIKO, PodGAinY, 2002; RED..., 2009]. Therefore it is considered as an ornithological sanctuary [ZAITSEV, AlEKSANDROV, 1998].

\section{Black Sea Biosphere Reserve}

A significant attraction for us the crossing of the shallow lagoon. Along with hydrobiologist - Darya Chernyakova - we have measured the water salinity and collected numerous specimens of invertebrates, which at the end of the day we determined together. However, they were not the only animals we saw, since also some livestock looked for refreshment on a hot July day. Especially cows paddled and waded in shallow water. Our presence did not disturb them at all in bathing. We returned to the base by land. Huge spiders were attracting particular attention. Despite their impressive size (over $5 \mathrm{~cm}$ ), they were hardly noticeable thanks to the perfect camouflage, which was provided by their earthy colours.

The true test of character for most of us turned out to be the climbing of the metal construction which was located in a central, probably the highest point of the steppe. It was the worth effort. From the top we had a stunning view. A mosaic of the Black Sea lagoons 
and shoals were spreading to the horizon. We spent the next day on a jeep tour through the reserve and could explore the diverse ecosystems of the steppe.

On the steppes enriched in salt by sea breezes, in the company of a predominating blue-green Artemisia santonica L. was also a halophytic carnation Dianthus guttatus Bieb., a West-Pontic endemic. Worth mentioning was Stipa capillata protected plant found also in the new edition of Red Data Book of Ukraine. In the steppe landscape our attention was drawn the by depressions with a more halophilous species growing in characteristic cushions Halocnemum strobilaceum (Pallas) Bieb., accompanied by just flowering tiny Frankenia hirsuta s.lat. and Limonium caspium (Willd.) Gams.

After some soup and fried fish, we have set for a walk along the bay, and then after few tiresome kilometres, the organizers surprised us with motorboat trip to a nearby colony of pink pelicans. Needless to say, that we were all delighted. The view of the colony of pelicans rising to fly was breathtaking. Of course, hundreds of photos were made. Thanks to the drivers courtesy, we saw also closely the juvenile individuals of these beautiful birds. Then we headed towards a small island inhabited by gulls and cormorants. We could closely observe the process of nest construction. After such a wonderful day, the participants expected only a peaceful way home. However, to our astonishment, it turned out that our accommodation was at the shores of the Black Sea and we could admire the sunset.

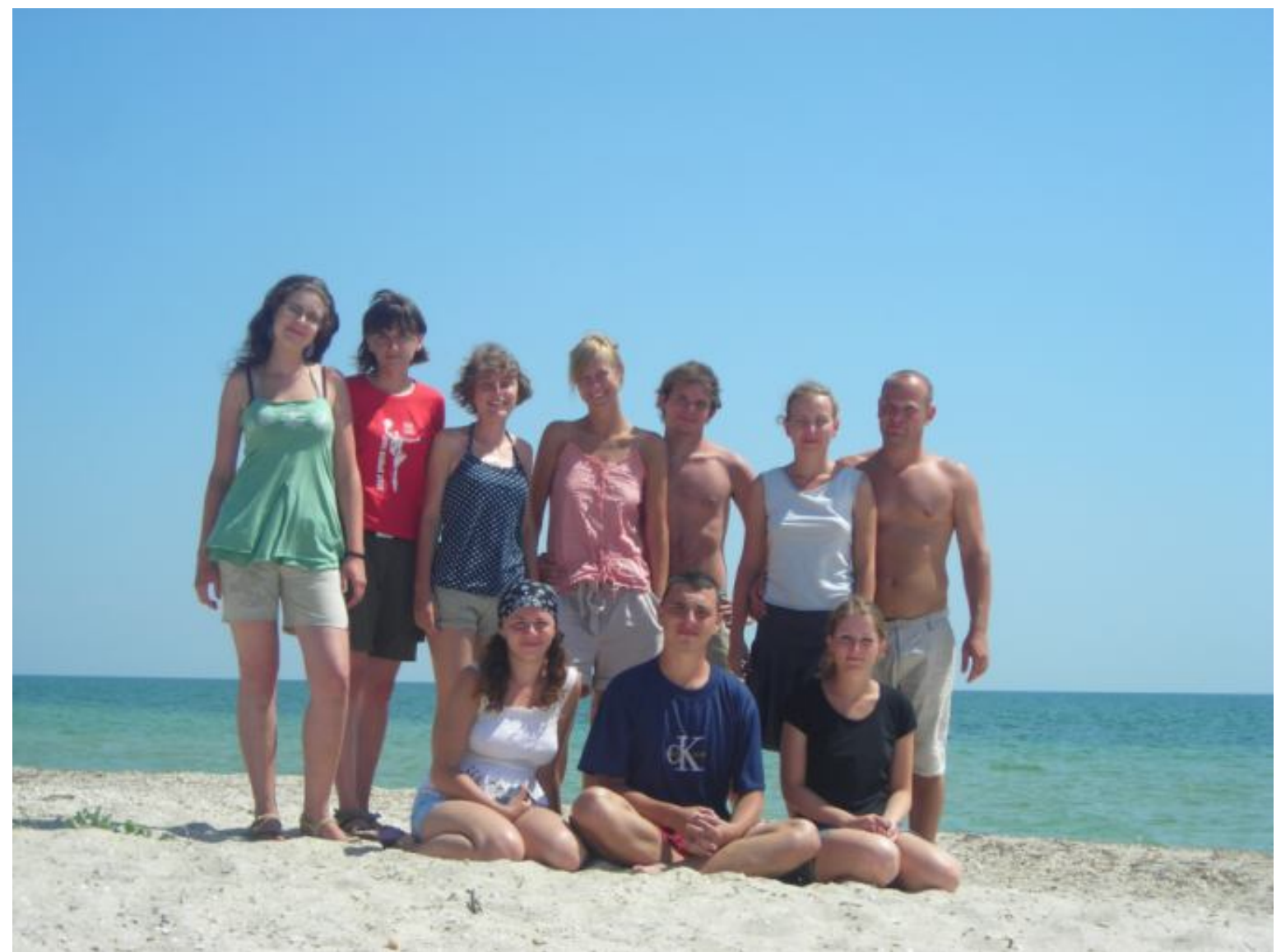

Fig. 1. A group of students taking part in student exchange 2010 between Faculty of Biology of Adam Mickiewicz University and Institute of Natural Science of Kherson State University. Standing from the left: Marta Warkocka, Sylwia Lukasik, Weronika Sura, Monika Gawalek, Krzysztof Dudek, Monika Zgrabczyńska, Lukasz Wiśniewski; siting from the left: Nastja Shkuropat, Vitalii Dyshlyk, Daniela Chmielewska.

Paradise beach....

Many participants of this expedition consider three days spent on the beach of Black Sea to be the best. Swimming in the sea brought us refreshment after bird watching. The 
northwestern Black Sea has relatively high level of salinity ranging from 10 to $18 \%$, as well as high temperature 10 to $26^{\circ} \mathrm{C}$ [ZAITSEV, ALEKSANDROV, 1998], as compared to ca 4-6\% and -2 to $25^{\circ} \mathrm{C}$ temperature of the Baltic Sea [KAUTSKY, 1991]. Its fauna has turned out to be different and very interesting to us. A special surprise was the opportunity to observe the passing dolphins, sometimes very close to the shore. Apart from them, a considerable number of individuals of scyphozoa, mainly Aurelia aurita, as well as fish species such as Engraulis encrasicolus, Trachurus trachurus and Scomber scombrus swam in the sea.

Extensive beaches were entirely covered with a layer of shells, including those of the beautiful predatory snail from the genus Rapana. In the hinterland we were admiring the vast and flat areas once flooded by salty seawater of the Black Sea, which after drying out got a crust of salt and other minerals on the top. These areas were overgrown only with halophytic Salicornia prostrata Pallas. Thanks to these walks, the students collection of natural treasures enriched in few interesting bird skeletal remains. Of course there was also left some time to relax on the beach and for sunbathing. To the friendly atmosphere in the evenings, contributed meetings with hosts and tutors, and talks lasted until late in the night.

\section{Summary}

Our attention was drawn not only by the Ukrainian landscape, but also by the architecture, like impressive railway stations, especially in Odessa and Lviv, by the streets and parks named after Lenin, and by his monuments. However, unique were the marketplaces, both in large cities and in smaller towns, with wide range of products: from clothes, spices, vegetables and candies to seafood, and even raw meat. At the bazaar every merchant praised his goods, and encouraged to try - cheese, wine or sunflower halva crumbs. A trip to the Kherson Oblast and knowledge gained there will remain long in the memory of Adam Mickiewicz University students. This great experience was possible thanks to the cooperation between Adam Mickiewicz University of Poznań and the Kherson State University, which has been lasting already for over 10 years.

\section{References}

Boiko M.F, PodgainY M.V. Red-list of the Kherson Region.- Kherson: Ailant, 2002. - 32 p. (in Ukrainian).

DiDUKH YA. P. (ed.). Red Data Book of Ukraine. Vegetable Kingdom. - Globalkonsalting: Kiev, 2009. - 912 p. (in Ukrainian).

KAUTSKY L. 1991: Życie w Bałtyku. Życie Morza Bałtyckiego. Z 2.

Protopopova V.V, SheVera M.V \& Mosyakin S.L. Deliberate and unintentional introduction of invasive weeds: A case study of the alien flora of Ukraine // Euphytica. - 2006. - Vol. 148. - P. 17-33.

Protopopova V.V, Shevera M.V, Melnik R.P. The History of Introduction and Present Distribution of Elaeagnus angustifolia L. in the Black Sea Region of Ukraine // Chornomors'k. bot. z. - 2006. - Vol. 2, N2. - P. 5-13 (in Ukrainian).

Prokudin Ju.N., Dobrocsaeva D.N., Zaverukha B.V., Csopik V.I., Protopopova V.V., Krickaya L.I. (eds.). Opredelitel vysshikh rastenii Ukrainy. - Kiev: Naukova Dumka, 1987. - 471 p. (in Ukrainian).

Zaitsev Yu. P., AleXAndrov B.G. Black Sea Biological Diversity Ukraine, Odessa Branch, Institute of Biology of Southern Seas, National Academy of Sciences of Ukraine, UN Publications, New York. 1998. - 349 p.

Рекомендує до друку

Отримано 01.05.2011 p.

А.В.Сна

Aдреса авторів:

С.Лукасік, К. Дудек

М.Гавалек, М. Зграбчинська

Біологічний факультет

Познанського університету

Ім. Адама Мічкевича

Вул.. Умультовська, 89

м.. Познань 61-514 Польша
Autor's address:

M. Lukasik, K. Dudek,

M. Gawalek, M. Zgrabczynska

Faculty of Biology

Adam Mickiewicz University

89, Umultowska str.

61-614 Poznań (Poland) 